\title{
Recognition and justification: Towards a rationalisation approach to inculturation
}

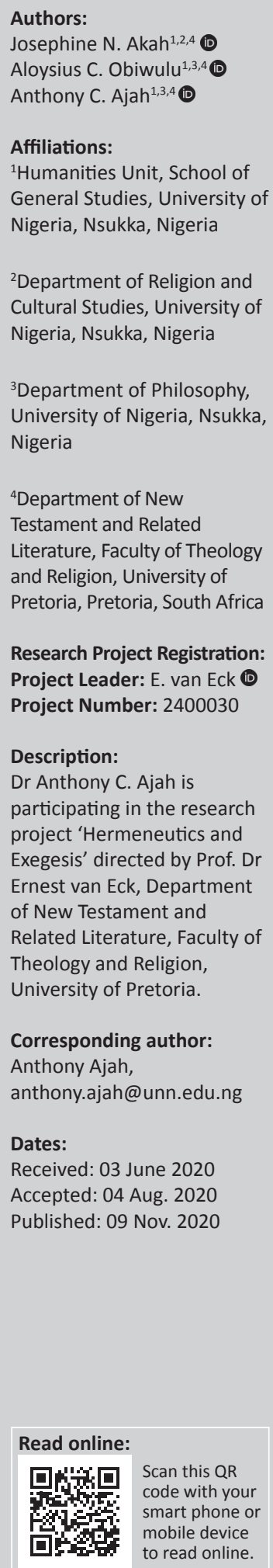

Several religious and theological approaches to culture in African studies have assessed the idea of inculturation as a helpless incorporation of cultural values from one culture into another. We showed in this article that this is a limited perspective to the process of inculturation, and that this limitation is the reason for the failure of several attempts at inculturation. We assessed inculturation from the angle of marketisation of cultures, and we argued that the adoption or adaptation of cultural elements from one culture into another should be an agentic rationalisation process. The article demonstrated that the rationalisation process is validated by pre-adoption pragmatic experiences or expectations such that the feature(s) being adopted has either initially proven - or at least is expected - to be more useful than what it is meant to replace or enhance. We concluded that a rationalisation approach to inculturation is based on an initial recognition of conceptual entities and practices, the need to adopt them, and a followup justification for this need. Without such perspective, an inculturation effort will not be successfully completed, sustainable or mutually respectful.

Contribution: Our primary contribution is that we tried to provide broad, agentic, rational approach to inculturation. This contribution is important in sub-fields of Christian Church History and Philosophy of Religion. It properly aligns with this journal's focus on history of religions, as well as phenomenology, and philosophy of religion(s).

Keywords: inculturation; recognition; justification; adoption; pragmatism; rationalisation; culture; marketisation.

\section{Introduction}

Inculturation remains a central issue in religious, cultural and intercultural studies. Several religious and theological approaches to culture in African studies have unknowingly assessed the idea of inculturation as a helpless incorporation of cultural values from one culture into another. We show in this article that, firstly, this is a limited perspective to the process of inculturation and, secondly, the limitation of this perspective is the reason for failure of several attempts at inculturation. To sample our position about the limited perspective to inculturation, we assess the official positions of specific Christian authorities (John Paul II 1990; Pius XII 1951). We also single out a recent suggestion by Nche, Okwuosa and Nwaoga (2016) on how to improve inculturation in Africa. We then show how the failure of the suggestions by the authors and others like them result from the limited perspective to inculturation.

The major limitation we identified in most arguments around inculturation is that by default, they conceive inculturation as something that is done with the 'approval' of Western Christian cultural vanguards; Nche et al. (2016:6) described them as 'stakeholders'. There is also a certain unwillingness to see Christianity as a cultural option among others. There is rather an entrenched supposition that Christianity has something special to offer, which has to be re-interpreted for eased acceptance by or 'incarnation into' (John Paul II 1990; Nche et al. 2016; Shorter 1973) the receiving cultures. From the point of view of this supposition, the proponents accept that inculturation as it has been practised needs to be improved. They also go ahead to indicate how it can be improved. But the suggestions do not include a re-conceptualisation of the process itself. We argue that as long as the current conceptualisation of inculturation prevails, in which the focus is on ensuring acceptance of Christian culture as 'faith', there are very few chances of

How to cite this article: Akah, J.N., Obiwulu, A.C. \& Ajah, A.C., 2020, 'Recognition and justification: Towards a rationalisation approach to inculturation', HTS Teologiese Studies/Theological Studies 76(3), a6186. https://doi.org/10.4102/hts.v76i3.6186

Copyright: (C 2020. The Authors. Licensee: AOSIS. This work is licensed under the Creative Commons Attribution License. 
successful, sustainable and mutually respectful inculturation. We demonstrate why we adopted this position. Our demonstration will not be based on cases of inculturation in particular contexts. Although that would be an impressive route, we rather focused on conceptual clarification of what is limiting in the prevailing views of inculturation, as well as why and how that limitation can be corrected by considering a rationalisation approach to inculturation. For this improvement, we explored the idea of 'rationalisation' by Meyer and Jepperson (2000) and adapted their views.

To achieve our aims, we divided this contribution into three sections after this Introduction. The first section is a broad presentation of the prevalent conceptions of inculturation, moving from the predominantly Christian conception of inculturation to a sociological one. In the second section, we initiate an argument for a new approach to inculturation centralised on pragmatism. In the third section, we further reconceptualise inculturation as a process of rationalisation. We explore the views of Meyer and Jepperson (2000) on agency generally, and cultural construction in particular, and then look at rationalisation from two perspectives, namely, as a process of recognition of cultural entities and as a process of justification of the need for adopting the entities. We concluded that a rationalisation perspective to inculturation should be based on an initial recognition of the entities to be adopted, as well as the need for these entities. The question of recognition should be followed by justification at both individual and collective action levels, on the practical and social need for the adoption/adaptation.

\section{Inculturation: The prevailing perspective}

In this section, we present the prevailing Christian origin of the concept of inculturation. We also present, very briefly, a broader definition of the concept. Our latter presentation will serve as the basis for our assessment of the weaknesses of the prevailing perspective. Inculturation has been mostly conceptualised and used within the Christian, particularly Roman Catholic, context. In this context, it has been sharply seen as the adaptation of Christian liturgy to a nonChristian culture. This 'sharp' definition presupposes that inculturation is one directional. However, inculturation has also been defined as the adaptation of Church teachings to fit other non-Christian cultures and contexts, as well as the adaptation of those teachings in response to the influence of those cultures on the evolution of the teachings. This latter conceptualisation provides a somewhat two-directional process. Yet, this aspect of inculturation is not taken seriously in the cultural interaction between Christianity and African cultures, for instance. We shall come to this later.

A quick distinction is important here: inculturation is neither enculturation nor acculturation. The three concepts are different. Enculturation emphasises learning experiences one acquires whilst living in a given culture. According to Crollins (1986:135), 'enculturation indicates the learning experience by which an individual is initiated and grows into his culture'. Schineller (1990) distinguishes acculturation from inculturation by indicating that acculturation is more a sociological process where inculturation fits better in a theological discourse. Ember and Ember (1981:325) defined acculturation as 'the changes that take place when different cultural groups come into intensive contact'. The intensity that defines acculturation requires that the cultural agents involved in the process have to clearly respond to questions relating to (1) which aspect of a foreign culture to adopt, (2) which aspect to reject, (3) which aspect of their own culture to eliminate and (4) how to transform whatever core cultural and norm practices that may be affected in the course of the changes (Thurnwald 1932:557-559). In this sense, acculturation is an engaging collective action process. It brings on board the agentic element of human engagement, namely, reflexive assessment of available options before making a choice. Having clarified these two concepts, let us return to our task of presenting the prevailing perspective to inculturation which has been predominated by positions from Catholicism.

The question of inculturation falls within the Christian idea of missionary mandate to go to all nations, preach to them and convert them. This implies an effort to relate with prospective converts within the context of their cultures. It has been noted that, between 1919 and 1959, there are about five papal encyclicals that redefined the Church's missionary role in response to several years of massive rejection of Christianity in societies like China (Kroeger 2013). These documents are Rerum Ecclesiae (Pius XI 1926), Summi Pontificatus (Pius XII 1939), Evangelii Praecones (Pius XII 1951), Fidei Donum (Pius XII 1957) and Princeps Pastorum (John XXIII 1959) (see Kroeger 2013). We single out for discussion the conceptualisation of inculturation by Pius XII because he was understandably more elaborate on the issue than the author of the first document, Pius XI.

Within the framework of these ecclesiastical documents, it was all about introducing the Christian Gospel to other cultures. For Pius XII, therefore, '[T] he magnanimous and noble purpose which missionaries have is the propagation of the faith in new lands' (1951:No.24). For this reason, Pius XII emphasised that the introduction of the Gospel means inculturation and not the destruction of local cultures; thus, 'a deeper appreciation into the various civilizations and their good qualities are necessary to the preaching of the Gospel' (Pius XII 1951:No.56).

Several years later, when the forces of globalisation had increased global awareness of various human cultures, John Paul II (1990) made a striking explanation of the basis for inculturation. He wrote: 'As she carries out missionary activity among the nations, the Church encounters different cultures and becomes involved in the process of inculturation' (1990:No.52). John Paul II defined inculturation in terms of a process of 'insertion' and therefore as 'the incarnation of the Gospel in native cultures and also the introduction of the cultures into the life of the church'. The process, he emphasised, is a lengthy one. It is not just an external adaptation movement in which the Church tries to influence the cultures that it meets; 
rather, it involves an 'intimate transformation of authentic cultural values through their integration in Christianity and the insertion of Christianity in the various human cultures'. Still in the metaphoric constructs of insertion and incarnation, John Paul II pictured a two-directional process in which, on the one hand, 'the Church makes the Gospel incarnate in different cultures', and on the other hand, she:

[I]ntroduces peoples, together with their cultures, into her own community. She [the Church] transmits to them her own values, at the same time taking the good elements that already exist in them and renewing them from within. (John Paul II 1990:No.52)

But then, there is a caveat: John Paul II added that the process is a difficult one because 'it must in no way compromise the distinctiveness and integrity of the Christian faith'. This caveat, in our view, bespeaks an idea of inculturation that is not initiated on a supposition that the cultures Christianity meets will have any contribution to the core features of Christianity. Rather, Christianity comes to each of the cultures feeling distinctive, with the goal of 'renewing ... from within' the values that belong to the cultures it meets. It is from this perspective that the idea of 'a very superficial type of Christianity on African soil' (Mbiti 1969:15) is a complaint against an unsuccessful effort at inculturation. We shall consider this later when we assess the prevailing conception(s) of inculturation. For now, we sum the above accounts of inculturation as the missiological use of the term. Let us assess their manifestations in non-papal positions, specifically in the suggestions of Nche et al. (2016) on how to improve inculturation in Africa.

The focus of the suggestions by Nche et al. is to 'safeguard the essence of the gospel' (2016:1). In our assessment, this is a confirmation of the idea of 'propagation' (Pius XII 1951) and a re-echo of the injunction that inculturation as a process should not compromise the 'distinctiveness and integrity' (John Paul II 1990) of the Christian faith. Nche et al. recalled the centrality of the concept of inculturation at the Second Vatican Council in 1962 and the subsequent Synod of Bishops for Africa, which took place in May 1994. Four ways of conceptualising inculturation can be noted in the work of Nche et al. (2016): (1) it is the expression of the dynamic relation for the consolidation of the faith; (2) it is a process to root Christianity in different cultures; (3) it is a process whereby Christianity's exposure to other cultures is aimed to transform the cultural values of the cultures involved; and (4) it is the contextualisation of the Christian faith (Nche et al. 2016). To sum it up, the authors added that in relation to Africa, inculturation is a movement for the Africanisation or indigenisation of Christianity in Africa (Nche et al. 2016:2). These positions are related to Shorter's (1973) argument that Christianity in itself is a type of faith, not a type of culture; and for this reason, it cannot adapt itself because doing so would result in self-betrayal. Shorter (1973) emphasised that the most Christianity should be expected to do, in its contact with a new culture, is to 'incarnate' itself in the new culture to challenge and transform the culture.

To achieve what they termed 'Africanised Christianity' or 'a satisfactory homemade Christian faith in the continent', Nche et al. (2016) itemised three 'salient' or priority issues.
The first issue is 'the evolutionary African culture'. This requires that ' $[i] n$ carrying out the task of inculturation in Africa ... it would be misleading to call for the recovery of African cultures in their pristine purity' (Nche et al. 2016:5). The second is 'the unity of the church/Christendom'. It requires that in order not to further sever the relationship, cooperation and unity amongst Christian denominations, every effort at inculturation should begin with consultations with Christian stakeholders. The third and final issue is termed 'Christian ecological concern'. This requires consistent attention to the need for 'ecological consciousness in Christendom' such that efforts are made to reduce destruction of natural habitats in the process of evangelising groups and societies. Nche et al. (2016:6) argued that whereas 'African cultures are replete with values and belief systems that promote the integrity of the ecosystem', any effort at inculturation should ensure that such values are not destroyed to the detriment of ecological stability and increased crises in climate change. In the third section of this essay, we shall assess conceptualisations of inculturation presented so far and the suggestions that are based on them. For now, let us sum the prevailing definitions of 'inculturation' and relate them to the sociological view of the term.

The presentations based on papal documents explain why it is common to hold that the idea of inculturation is as old as the church. Metuh's (1966) account of the origin of the concept of inculturation is from a secular perspective. According to him, the term is borrowed from cultural anthropology, where it denotes the process by which a person is inserted into his or her culture. This secular perspective seems to have been overshadowed by the missiological use explained in the preceding paragraphs, which presents the concept as a process by which Christianity becomes inserted into other cultures. Despite this overshadowing, it could be accepted that 'at its best, the term combines the theological significance of incarnation with the anthropological concepts of inculturation and acculturation to create something new' (Schineller 1990:21). Based on this view of Schineller, we conceptualise inculturation as a process of intentionally adopting an entirely new cultural element from another culture or adapting what is already in a culture to reflect a better version of it that exists in another culture.

Regarding intentionality, we focus on how a true process of inculturation needs to be driven by a sense of usefulness (pragmatism) of what is being considered for adoption/ adaptation. We also focus on how such a process requires an underlying recognition of and justification for the conceptual entities that will be introduced by means of the new cultural features that are being considered for adoption.

\section{Inculturation as a pragmatic process}

We stated earlier that inculturation entails adopting and adapting new elements from one culture to another. We argue in this section that what should prompt the desire 
for this change or adaptation are pre-adoption experiences of usefulness and workability of the elements that are to be inculturated.

One of the characteristics of culture is that it is dynamic. This should mean that every culture changes, either by intentionally taking in new elements from other cultures or by shedding off some of their old elements. The idea of 'taking in' new elements takes place in two ways: (1) acculturation and (2) inculturation. Although we had hinted on the meanings of these terms earlier, we shall refer to them again to buttress our point. Segall et al. (1999) held that:

$[A]$ cculturation comprehends those phenomena which result when groups of individuals having different cultures come into continuous first-hand contact with subsequent changes in the original culture patterns of either or both groups. (p. 301)

During the process of acculturation, cultural change may take place in any of the two cultures that interacted. According to Segall et al., the culture or group in which more change is induced or introduced is regarded as the 'acculturation group', whilst the one that brought about the change is termed the 'dominant culture'.

Inculturation, however, is an aspect of the adoption of a new culture, during which the primary culture is still retained but at the same time aspects of the new culture are imbibed or adapted. When the primary culture is totally lost to the new culture, one then talks of cultural assimilation. Assimilation could occur for several reasons, but the discussion is not our concern now. It suffices to say that when assimilation takes place, one's culture is lost. But in adaptation, the outcome of the cultural contact is different:

In its most general sense, adaptation refers to changes that take place in individuals or groups in response to environmental demands. The adaptations can occur immediately, or they can be extended over the longer term. Short-term changes ... are sometimes negative and often disruptive in character. However ... after a period of time, some long-term adaptation to the new cultural context usually takes place. (Segall et al. 1999:309)

So far, we have explained that inculturation takes place when a culture accepts some elements from another culture and adapts to them in the long term. We argue that this is possible because the receiving culture considers as interesting, or in fact useful, those elements from a new culture. They are interesting because they are considered as having some pragmatic advantages for the receiving culture.

Pragmatism is a philosophical theory which emphasises the workability and usefulness of principles, opinions, views, ideas and theories. The term is derived from the Greek word pragma, which means action or affair. The Greek historian Polybius described his writings with the term 'pragmatic', meaning that they were intended to be instructive and useful to his readers (Online Encyclopaedia Britannica: https:/ / www.britannica.com/topic/pragmatismphilosophy). Following from this description, a thing (an idea, action or theory) is considered pragmatic if it aims at solving problems instead of just propounding theories and citing precedents. As conceptualised in Enyclopaedia Britannica, pragmatism is a:

[S]chool of philosophy, dominant in the United States in the first quarter of the 20th century, based on the principle that the usefulness, workability, and practicality of ideas, policies, and proposals are the criteria of their merit. It ... holds that ideas borrow their meanings from their consequences and their truths from their verification. Thus, ideas are essentially instruments and plans of action (Online Encyclopaedia Britannica: https:// www.britannica.com/topic/pragmatism-philosophy).

Pragmatism was borne out of the need to deemphasise the use of ideas that were often abstract and unable to be implemented. It emphasises usefulness. The extreme version of it accepts that whatever works is useful and should be accepted.

When we say that inculturation is a pragmatic process, we are arguing that pre-inculturation experiences should show that the cultural element being adopted had proven to be more useful than what it was meant to replace. Pragmatic experience serves as a reason for justifying the adoption or adaptation. In other words, the new elements should have been adjudged either in hope or based on prior concrete experiences as useful, workable, interesting and fulfilling, before they are adopted and adapted. Thus, a culture accepts an element from a new culture when the element is seen, or highly promises, to enrich the receiving culture. According to Meyer and Jepperson (2000:101), inculturation in this sense is a cultural construction and not just a metatheory about actors and their agencies.

Our interest in drawing attention to the importance of pragmatism in any inculturation process that deserves the name is that no group of people willingly wishes their cherished culture to die off. This is one of the reasons there is often cultural refusal and acrimony towards other cultures because one wants one's culture to survive. However, useful elements are permitted, especially where they bring in what was absent in the other culture.

We demonstrate that inculturation is meaningful, successful and sustainable when there is an obvious or perceived advantage, usefulness and workability of what is to be adopted. This fact was attested to by Jared Diamond (1999) when he discussed how interest and usefulness necessitated the domestication of animals and crops (like dogs, pigs, hemp, citrus fruit, tea, apricots, peaches and pears) in ancient China, as well as the cultural exchanges that took place. This buttresses the idea that mutually respectful cultural exchanges or inculturation takes place because of the profitability or workability of the exchange, where one culture has something to gain from the other culture by modifying what it previously had. It is so because 'humans have the capacity and responsibility to modify society and to intervene' (Meyer \& Jepperson 2000:103). This process of modification is undergirded by a deeper process of rationalisation, which we now explore. 


\section{Inculturation as rationalisation}

A perspective to inculturation that receives the least attention is the idea that it involves the gradual acquisition of the characteristics and norms of a culture or group by another person or culture. In defence of this largely ignored perspective, we demonstrate in this section how inculturation should neither be just a helpless option nor an option for the weak. It should be a process that involves gradual choices that are influenced by factors such as recognition of entities, usefulness, cultural sustainability and desire for self-enhancement. By not being 'just' a helpless option, we mean that it is not the only option left to be taken. By not being an option for the weak, we mean that it is not forced on those who take them.

We had discussed in the last two paragraphs how inculturation is a pragmatic process. The pragmatic feature of inculturation is one of the characterisations of what we mean by rationalisation. We derive the term 'rationalisation' from the views of Meyer and Jepperson (2000) that modern social actors, as social agents, are not natural entities as such, but results of continuous social construction and reconstruction. The direction of the process of construction, according to them, is based on particular reasons at each stage. This means that reasons direct the process of (re) construction of agency. Considering that the typical social process under discussion is inculturation, and that reasons define each construction, we therefore state that inculturation should be a rationalisation process. It should be the rationalisation of culture. Rationalisation in this sense entails, on the one hand, a recognition of cultural elements and entities as worthy of attention and inclusion. On the other hand - as a result of the first sense - it is a process in which justifications are made for the choice of which cultural feature is in need of modification, which needs to be adopted, which should be sustained and which should be abandoned and allowed to die. First, we explain the views of Meyer and Jepperson (2000). Second, we apply the framework of their views to the idea of how inculturation is a rational process.

In their article titled "The "actors" of modern society: The cultural construction of social agency', Meyer and Jepperson (2000) set out to show how the idea of modern agency is the result of ongoing relocation of agency, from transcendental authority or natural forces to capable humans. The focus was on humans broadly speaking, that is, either as individuals, groups or states. Their primary supposition is that human agents are not autochthonous and natural entities; instead, they are 'historical and ongoing cultural construction' (2000:101). This supposition, according to them, is based on two departures. The first departure is that the actorhood of individuals, organisations and national states is an elaborate system of social 'agency' that was pre-dated by a long and continued religious and post-religious evolution. In this regard, Meyer and Jepperson argued that what is at stake is an ongoing relocation of agency, from transcendental authority (gods) and/or natural forces environing the social system, into the society. These gods and transcendental authorities, according to these authors, are 'exogenous forces'. Relocation of their agency has enlarged social agency by 'relocating authority from god to church, from church to state, from church and state to individual souls and later citizens' (Meyer and Jepperson 2000). This process warrants that we:

[S]ee the development of modern actorhood as more a cultural devolution - from god to society, on to individuals and organizations - than a natural evolution from less to more social complexity, or an aggregate product of interest-based struggles over natural given goals. (p. 101)

The second point of departure is that modern actors have been constructed as authorised agents for various interests. One of the implications is that an individual or group is able to engage in 'broad collective purposes' (2000:101), including the ability to act on behalf of others - a group, the poor and a universal principle. Our particular interest in this essay is on the first departure, and we shall explore it a little further in the authors' presentations.

Meyer and Jepperson (2000:102) conceptualised the idea of rationalisation as recognition of social entities. It refers 'to the cultural accounting of society and its environments in terms articulated, unified, integrated, universalized, and causally and logically structured schemes'. Rationalisation basically includes the instrumentalisation of the society and nature in general, in such a manner that both of them and all they imply are modifiable. It 'creates a constantly expanding set of recognized entities with their functional interrelations and often associated legitimated "interests"' (Meyer \& Jepperson 2000:104). It involves recognition of new elements that are included in a society's conceptual framework about reality as a whole, and about the society in particular. In this last regard, it is insightful to note that there is a close causal link and high degree of interpenetration between rationalisation of nature and rationalisation of society. On the one hand, 'human activities and social organizations must take into account the imagined lawful entities and relations in the natural environment'. On the other hand, 'the enriched analysis of nature .... also provides agenda for expanded rational human activity: new analyses create a constant flow of new social problems and possibilities' (2000:104). These positions of Meyer and Jepperson (2000:104) can be summed by the expression that '[T]he rationalisation of nature does produce an expanded set of recognized entities and relations'. Every effort, therefore, at human recognition and reconceptualisation of what is important, what should be given attention, which is different from previous dictates of religious systems, can be described as rationalisation. So how do Meyer and Jepperson's ideas about rationalisation provide a framework for our view that inculturation is a process of rationalisation? We answer this question in the remaining paragraphs of this essay.

Let us first provide a definition. In the context of this discussion, we conceptualise the term 'rationalisation' from two closely related perspectives: (1) as a recognition of 
cultural elements and entities as worthy of attention and inclusion in a conceptual framework and categorisation and (2) as provision of justifications for a choice of action, which may include the acts of recognition and adoption of cultural entities. Still for the purpose of this discourse, we stretch the second feature of rationalisation we just presented to also mean a process in which justifications are made for the choice of which cultural feature is in need of modification, which needs to be adopted, which should be sustained and which should be abandoned and allowed to die.

We had defined 'inculturation' as a process of intentionally adopting an entirely new cultural element from another culture or adapting what is already in a culture to reflect a better version of it that exists in another culture. We had also hinted that inculturation is not a helpless incorporation of some cultural values from one culture to another. Instead, we look at inculturation from the angle of marketisation of cultures, to argue that the adoption or adaptation of cultural elements should be an agentic rationalisation process in which those adopting a cultural element consider the overall advantages or usefulness of adopting and retaining one feature from one culture into another cultural framework. We also demonstrate that this agentic rationalisation process is validated by pre-adoption pragmatic experiences or expectations such that the feature being adopted has either initially proven - or at least is expected - to be more useful than what it is meant to replace or enhance. We now defend these latter claims.

What do we mean by looking at inculturation from the angle of marketisation of cultures? How does that help our argument that inculturation is a rationalisation process? These are the two questions that will occupy our attention first. The concept of market is a space where individuals compare possible items in terms of price, usefulness, durability and satisfaction. Based on these comparisons, individuals are able to choose which items they prefer to others in the same class. It is from this perspective that we look at marketisation of cultures as a conceptual space in which cultural frameworks and systems are taken as separate items amongst other possible items. Within that conceptual space, comparisons are made between whole cultural frameworks or systems, or individual features of these systems. In this conceptual space also, individuals trade cultural values and features and make their choices in terms of comparative usefulness, durability, satisfaction and clarity of perception of reality. This is the framework that defines our preferred understanding of inculturation as a process that is structured by the principle of marketisation of cultures. The adoption or adaptation of cultural values and practices, from one cultural framework or system to another, should involve a form of trade in which one feature is rationalised, recognised, justified and therefore adopted to either take an entirely new space in the receiving system or to enhance what was previously there but in need of enhancement.

There are two ways this understanding of inculturation can help our argument that inculturation is a rationalisation process. The first way is that the adoption of values or features or even practices from another culture is, on the one hand, a type of recognition of those entities. On the other hand, the adoption is an acknowledgement of an initial need on the part of the cultural agents involved in the adoption. The second way is that the understanding of inculturation as marketisation brings up the idea of justification that drives inculturation: what is adopted must have been perceived to be of some usefulness. We shall explain these points together. Adoption of a cultural feature or value, from one system to another, implies a recognition of, say the reality of, the entities embodied in the values. Only what is recognised as existing can be considered for adoption in the first place. From this perspective, to aim to adopt 'value $X^{\prime}$ from a certain culture implies an initial assessment and acceptance that 'value $X^{\prime}$ is a reality - for instance, a conceptual or moral reality.

This leads to the next crucial question: granted that 'value $X$ ' exists, of what relevance is its adoption for our conceptual or value system? Put in another way, why do we need 'value $X^{\prime}$ '? This is the question about justification of pragmatic relevance and rationalisation as the 'reason for action'. If 'value $X^{\prime}$, for instance, helps the adopting society to understand - like never before - why it is possible for a woman to give birth to more than one offspring in one pregnancy, that means that 'value $X^{\prime}$ has broadened the conceptual framework of the society that adopted it. It has expanded their understanding of reality. If that same adoption results in ending the killing of twins by that society, that means the same adoption has led to the end of killing innocent children and the end of the misery of women whose children are killed just because they are twins - out of no fault of the children or the mother. Thus, beyond what may be considered as mere expansion of the conceptual framework of the society, there is also a grave social relevance of the same adoption. These considerations constitute sufficient justifications for the adoption of our sample 'value $X^{\prime}$.

The last point in the last paragraph provides a link to answer our last set of questions. How does the idea of rationalisation reconnect with pragmatism? Why do we need both concepts to improve our understanding of inculturation? With regard to the first part of the question, we submit that rationalisation reconnects with pragmatism because the latter is the basis for the former. An entity is recognised and accepted into a conceptual framework because of its usefulness in a broad understanding of reality, as well as in an improved organisation of the society. Besides, justifications for the inclusion or adoption of a (new) entity, feature or concept into a system or framework are usually driven by usefulness. This means that the idea that inculturation is a rationalisation process is based on the other idea that it is a pragmatic process. We need both concepts for clearer understanding of inculturation because neither of the concepts can stand without the other, and each needs the other for an improved understanding of inculturation. Our perspective can be summed as emphasising the role of cultural agents in the receiving culture, in the inculturation process. We agree that this is our focus: a core agentic interpretation of inculturation in which the emphasis 
is not on the culture from which the value is being adopted, as evident in missiological conceptualisation of inculturation, but on the culture that is adopting the value.

The position we presented so far could be considered as not offering a broader understanding of inculturation as we indicated. One could argue that it is not different from the usual conceptualisations of inculturation. One major reason stands out in this regard. From historical experiences, particularly 'inculturation' as a tool for spreading Christianity in general and Catholicism in particular, the process has remained a tactic for making the receiving cultures adopt the values from the 'superior' culture. As such, the vanguards of the superior culture imposed the values and practices in question, with neither an initial attempt to justify and convince nor a waiting period for the receiving culture to indicate that it has recognised the relevance of the values and entities being introduced. Our response in this regard is that this is not a case of inculturation but of (cultural) imposition. From historical experiences too, it is evident that such impositions did not succeed in effecting an impressive transfer of the intended values to the receiving culture. This last point is closely related to the views of Obeten (2020). According to him, despite Christianity's efforts to evangelise societies in Africa, these efforts have largely failed because the approach that defined them was basically 'hostile to the idea of inculturation' (Obeten 2020:5). This could have been a sound critique of the process of inculturation in Africa. However, the author's argument failed because he conceptualised inculturation as incarnation. This is faulty. His views on inculturation were undergirded by his acceptance of the framework provided by John Paul II, which we think is in need of modification. Let us recall some earlier papal injunctions to further explore the basis for such failures.

In the first section of this essay, we had quoted Pius XII as having held that 'The magnanimous and noble purpose which [Christian] missionaries have is the propagation of the faith in new lands' (1951:No.24). We had also quoted John Paul II as emphasising that in the process of inculturation: (1) the Church introduces people and their cultures into her own community and (2) this process 'must in no way compromise the distinctiveness and integrity of the Christian faith' (1990:No.52). These views of inculturation from the drivers of Christian inculturation provide evidence for our initial claim that the prevailing Christian conceptualisation of inculturation is limited. Let us explain our position. The use of the term 'magnanimous' and 'propagation' by Pius XII shows, on the one hand, that the missionary will be doing some kind-hearted favours to those it will meet in the new lands. They are going to these lands from a superior standpoint of default, magnanimous benefactors. From this standpoint also, those to be met in the new lands have nothing to offer - they are pitiable recipients from the magnanimous and noble missionary. This is the basis for the fact that what the missionary is going to do doesn't require any real discursive interaction with those in the new land. Rather, the missionary is going to 'propagate' - an agriculture- based term that implies spraying seeds on fertile soils. The soils, as non-agents, are unworthy of any prior interaction and agreement. This perspective is also recurrent in the incisive warning by John Paul II, that the missionary should not compromise the 'distinctiveness and integrity' of the Christian culture (John Paul II 1990:No.52).

Again, the missionary is by default on a superior standpoint, and the features of the culture they come with are superior that its integrity should not be sullied by an excessively discursive interaction with the people whose duty it is to simply accept the distinctive culture. There is no room for the cultures in the new lands to freely interact with the Christian culture to first assess whether the features of the Christian culture and the attendant entities are worth 'recognising' within the frameworks of the cultures in the new lands. There was, therefore, also no room for these cultures to justify for themselves the need to change some concepts, conceptual categories and practices. Because of these lacks, it is clear from our framework that what was obtained was not inculturation. If at all it was intended to be inculturation, the conceptualisation of the process itself by those involved was limited and fundamentally flawed.

Limited conceptualisation of inculturation has been the conceptual deadlock for several discourses on inculturation in Africa, for instance. Kiarie (2019) accepted the view that inculturation is primarily a process of enabling people of every culture, locality and time to understand the Christian message. This implies that Kiarie is also involved in the misconceptualisation of inculturation. This is despite his cogent argument that one of the challenges of inculturation is 'ecclesiastical imperialism' (2019:11), a situation in which certain values are imposed on receiving communities. The idea of imposition is driven by a deeper drive to insert Christianity into cultures. Hence, Ballano (2020:1) sees inculturation as 'the process of inserting the Christian message in society'. This is again rooted in the view that inculturation implies incarnation of the Christian message. On the basis of these latter clarifications, we now assess the views of Nche et al. (2016) presented in the first section of this essay. First, let us explain the limitations in the definitions presented earlier and then respond to the underlying impact of those conceptual limitations on the suggestions by Shorter (1973) and Nche et al. (2016). Differing from Shorter (1973), we emphasise our use of the expression 'Christian culture', rather than 'Christian faith'. This conceptual stance is important from the perspective that what is termed faith is first of all a component of a broader cultural reality. Besides, faith implies belief in specific cultural values and principles. This view is aptly corroborated by John Paul II when he wrote that:

[T] he synthesis between culture and faith is not just a demand of culture, but also of faith. ... A faith which does not become culture is a faith which has not been fully received, not thoroughly thought through, not faithfully lived out. (2002:online)

To see Christianity as a culture, makes it more open for the interaction required in a true inculturation. Christianity's 
obviously massive failure at inculturation in many countries has been because of the predominant conceptualisation of Christianity as a faith, which is meant to be implanted, propagated and incarnated, with little or no influence from the interacting culture.

Because the conceptualisation of the term by both Shorter (1973) and Nche et al. is limited, their suggestions on how to improve inculturation have (Shorter 1973) and will (Nche et al. 2016) amount to very little improvement in inculturation efforts. On a general note, Nche et al. (2016) - like Van der Merwe (2016) - were only able to attach the geographic qualifier 'Africa' before Christianity (Nche et al. 2016) and Christian theology (Van der Merwe 2016) as their solution to the problem of a poorly executed process of inculturation, which amounted to poorly 'entrenched' Christianity in Africa. We think that the problem of poor mutual interaction between Christianity and cultures in Africa, for instance, is not solved by merely adding a geographic qualifier. Besides, the first suggestion by Nche et al. (2016), which is anchored on the idea of 'the evolutionary African culture', amounts to nothing. It is weak. First, every culture is evolutionary, so how is the term 'evolutionary African culture' a solution to a poorly conceptualised process? Second, that suggestion treats cultures in Africa as if they constitute a monolith. Attempts at homogenisation like this are particularly unproductive because specific experiences are blurred and lessons from specifics and varieties are lost.

\section{Conclusion}

Our aim in this article was to provide a broad and alternative approach to the idea of inculturation. We suggested that inculturation needs to be understood as a process of rationalisation. This approach, in our assessment, is better than the approach that sees inculturation as just a process of incarnating Christian faith into new lands and cultures. It is also better than another approach that presents inculturation as an option from a superior missionary Christian Church, which the weak must take. As an improvement on these approaches to understanding inculturation, we look at it from the angle of the adopting culture and based on the principles of marketisation. We argued primarily that inculturation needs to be seen as a process that involves gradual choices that are influenced by factors such as recognition of entities, usefulness of those entities, cultural sustainability and desire for selfenhancement. We sum all these factors by the term 'rationalisation', understood, firstly, as a process of recognising and including new entities into the adopting conceptual framework and, secondly, as a process of justifying the reasons for recognising these new entities.

\section{Acknowledgements}

We deeply thank University of Pretoria for paying the publication fee for this article. We thank the reviewers of our manuscript for their comments which improved the quality of our work. And we thank the editorial team of this journal for their excellent services.

\section{Competing interests}

The authors declare that they have no financial or personal relationship(s) that may have inappropriately influenced them in writing this article.

\section{Authors' contributions}

All authors contributed equally to this work.

\section{Ethical consideration}

This article followed all ethical standards for research without direct contact with human or animal subjects.

\section{Funding information}

This research received no specific grant from any funding agency in the public, commercial, or not-for-profit sectors.

\section{Data availability statement}

Data sharing is not applicable to this article as no new data were created or analysed in this study.

\section{Disclaimer}

The views and opinions expressed in this article are those of the authors and do not necessarily reflect the official policy or position of any affiliated agency of the authors.

\section{References}

Ballano, V., 2020, 'Inculturation, anthropology, and the empirical dimension of evangelization', Religions 11(2), 101. https://doi.org/10.3390/rel11020101

Crollins, A.R., 1986, Inculturation: Newness and ongoing process, Pauline Press, Nairobi.

Diamond, J., 1999, Guns, germs, and steel: The fates of human societies, W.W. Norton \& Co., New York, NY.

Ember, C.R. \& Ember, M., 1981, Cultural anthropology, Prentice-Hall, Englewood Cliffs, NJ.

John Paul II, 1990, Redemptoris Missio: On the permanent validity of the Church's missionary mandate, viewed 06 May 2020, from http://www.vatican.va/content/ john-paul-ii/en/encyclicals/documents/hf_jp-ii_enc_07121990_redemptorismissio.html.

John Paul II, 2002, Message to Cardinal Paul Poupard for the 20th anniversary of the Pontifical Council for Culture, viewed 06 May 2020, from http://w2.vatican.va/ content/john-paul-ii/en/speeches/2002/may/documents/hf_jp-ii_ spe_20020514_message-poupard.html.

John XXIII, 1959, Princeps Pastorum: On the missions, native clergy, and lay participation, viewed 05 May 2020, from http://www.vatican.va/content/john-xxiii/en/encyclicals/ documents/hf j-xxiii_enc_28111959_princeps.html.

Kiarie, G.K., 2019, 'Theological impediments to inculturation of the eucharistic symbols in the Anglican Church of Kenya', Studia Historiae Ecclesiasticae 45(1), \#4182. https://doi.org/10.25159/2412-4265/4182

Kroeger, J., 2013, 'Papal mission wisdom: Five mission encyclicals 1919-1959', in S.B. Bevans (ed.), A century of Catholic mission: Roman Catholic missiology 1910 to the present, pp. 93-100, Regnum, Oxford.

Mbiti, J.S., 1969, African religions and philosophy, Heinemann Educational Books, London.

Metuh, I.E., 1996, African inculturation theology: Africanizing Christianity, Imico, Ontisha.

Meyer, J.W. \& Jepperson, R.L., 2000. 'The "Actors" of modern society: The cultura construction of social agency', Sociological Theory 18(1), 100-120. https://doi. org/10.1111/0735-2751.00090 
Nche, G.C., Okwuosa, N.L. \& Nwaoga, T.C., 2016, 'Revisiting the concept of inculturation in a modern Africa: A reflection on salient issues', HTS Teologiese inculturation in a modern Africa: A reflection on salient issues', HTS Teologiese
Studies/Theological Studies 72(1), a3015. https://doi.org/10.4102/hts.v72i1.3015

Obeten, M., 2020, 'The indispensability of inculturation for effective evangelization: Revisiting the evangelization of Sub-Saharan Africa', School of Theology and Seminary Graduate Papers/Theses, viewed 03 May 2020, from https:// Seminary Graduate Papers/Theses, viewed
digitalcommons.csbsju.edu/sot_papers/1922.

Pius XI, 1926, Rerum ecclesiae: On Catholic missions, viewed 05 May 2020, from http://www.vatican.va/content/pius-xi/en/encyclicals/documents/hf_p-xi enc_28021926_rerum-ecclesiae.html.

Pius XII, 1939, Summi Pontificatus: On the unity of human societies, viewed 05 May 2020, from http://www.vatican.va/content/pius-xii/en/encyclicals/ documents/hf_p-xii_enc 20101939 summi-pontificatus.html.

Pius XII, 1951, Evangelii Praecones: On promoting Catholic missions, viewed 05 May 2020, from http://www.vatican.va/content/pius-xii/en/encyclicals/ documents/hf_p-xii_enc_02061951_evangelii-praecones.html.
Pius XII, 1957, Fidei Donum: On the present condition of the Catholic Missions, especially in Africa, viewed 05 May 2020, from http://www.vatican.va/ content/pius-xii/en/encyclicals/documents/hf_p-xii_enc_21041957_fideidonum.html.

Schineller, P., 1990, A handbook on inculturation, Paulist, New York, NY.

Segall, M.H., Dasen, P.R., Berry, J.W. \& Poortinga, Y.H., 1999, Human behaviour in global perspective: An introduction to cross-cultural psychology, Allyn \& Bacon, New York, NY.

Shorter, A.W.F., 1973, African culture and the Christian church: An introduction to social and pastoral anthropology, Geoffrey Chapman Publishers, London.

Thurnwald, R., 1932, 'The psychology of acculturation', American Ethnology 34(4), 557-559. https://doi.org/10.1525/aa.1932.34.4.02a00020

Van der Merwe, D., 2016, 'From Christianising Africa to Africanising Christianity: Some hermeneutical principles', Stellenbosch Theological Journal 2(2), 559-587. https://doi.org/10.17570/stj.2016.v2n2.a25 